Fragments Relating to the Saxon Invasion from an Unknown Canterbury Chronicle Author(s): E. W. B. Nicholson

Source: The Celtic Review, Vol. 2, No. 6 (Oct., 1905), pp. 197-199

Stable URL: http://www.jstor.org/stable/30070146

Accessed: 19-06-2016 23:05 UTC

Your use of the JSTOR archive indicates your acceptance of the Terms \& Conditions of Use, available at

http://about.jstor.org/terms

JSTOR is a not-for-profit service that helps scholars, researchers, and students discover, use, and build upon a wide range of content in a trusted digital archive. We use information technology and tools to increase productivity and facilitate new forms of scholarship. For more information about JSTOR, please contact support@jstor.org.

is collaborating with JSTOR to digitize, preserve and extend access to The Celtic Review 
the original Norse had a $k$ sound, and through regular sound changes it has become pràmh in Gaelic, with the form cnàmh, reminiscent of its original Norse form, and strengthened by the influence of the native cnamm. I agree with Mr. Robertson when he says in his excellent paper on the 'Variations of Gaelic Loan-Words,' that the different forms of this word suggest borrowing.

George Henderson.

\section{Fragments relating to the Saxon Invasion from an unknown Canterbury chronicle}

A good many years ago I referenced and bound a large number of leaves of MSS. which had been extracted (mostly before 1882) from the covers of Bodleian books. Among them were many Latin chronicle-fragments in similar writing - of the first half of the twelfth century-and of the same dimensions $(10 \times 7 \mathrm{in}$.) : moreover, the bindings out of which they had come were all executed (Mr. S. Gibson tells me) in the same Oxford binding about the beginning of the seventeenth century. One of the leaves, ${ }^{1}$ commencing a chronicle, is headed, in a twelfth century hand, 'Cronica iperfecta', and I have now no doubt that the entire collection formed part of the volume of 'Cronica inperfecta' which is no. 283 in Prior Eastry's catalogue of the library of Christ Church, Canterbury, recently printed by Dr. M. R. James (p. 49).

In $1899 \mathrm{I}$ saw that these fragments fell into two distinct groups, and I re-referenced them and re-bound them accordingly, after a further and successful hunt for additional related fragments in other Oxford bindings.

The first group now form MS. Lat. misc. d. 30 in the Bodleian. Except the leaf headed 'Cronica iperfecta', which is a chronology of emperors from Augustus to Justinian, they are all part of a chronicle of Old Testament history. Some of them, including the verso of the leaf in question, have twenty-nine lines to the page. I shall have no need to mention them further.

The second group now form MS. Lat. misc. d. 13. They are part of a general chronicle, cover the period A.D. 70-516, and are all from the pen of one scribe, whose hand is not found in the other group, and who always writes twenty-nine lines to the page.

It is with the latter group that this paper is concerned, and I call the chronicle unknown not merely because of my long and unsuccessful attempts to identify it, but because neither the Rev. C. Plummer nor the late Prof. F. York Powell was able to recognise it.

I append notes ${ }^{2}$ of passages relating to the Saxon invasion, and of corre-

1 F. 20 in MS. Lat. misc. d. 30 in the Bodleian.

${ }^{2}$ For convenience of printing I have always used dotted $i$. In the fragments there is, of course, no dot, but sometimes a stroke, and sometimes none. 
sponding entries in the Anglo-Saxon chronicles. The latter I indicate by the respective letters which Mr. Plummer uses in his Two Saxon Chronicles. The dates hardly ever agree.

A.D. 466, the battle near Wippedes fleot. As fleot has various meanings, and the water in question is unknown, the words "prope riuulum qui dicitur Wippedes fleot' are important.

A.D. 484, EElle's battle 'iuxta torrentem qui dicitur marcreder burna': 'torrentem' is a new particular, important because the stream is still unidentified.

A.D. 487, Beginning of Esc's reign of 27 years, which $\mathrm{A}$ B.C call ' $\mathrm{XxImI}$ ' winters, $\mathbf{E}$ 'xxxııı.'

A.D. 495, Alle and Cissa besieged 'ciuitatem andredes'-virtually identical with the Anglo-Saxon version, but 'in ore gladii perimerunt' (i. o. g. is a Biblical phrase) where that has only 'ofslogon'. A Latin entry almost identical is found under 490 in $\mathrm{F}$, and apparently in an earlier form, for it has perimunt.

A.D. 497, Invasion of Certic and Kyneric. Similar entry in A B-C E, and both in English and Latin in F.

A.D. 501, Invasion of Port, Beada, and Megla. Similarly T B.C E (all Bieda and Mrgla), also in short English and shorter Latin in F, with Biedda and Mægla (Lat. Mogla).

A.D. 507, Nataleod and 5000 Britons killed. Almost identical Latin entry in F, but its Anglo-Saxon entry, like F B-C E, only says that the 5000 were with him : the Latin version is incredible, and obviously arises from an omission of wera (or erant) in 'wera mid him' (or 'erant cum eo').

The connexion with F (MS. Cott. Domit. A. vill in the British Museum) cannot be doubted, and that (Plummer, Two Saxon Chronicles, II. cxxii) was made in the late eleventh or early twelfth century from an original Saxon chronicle belonging to St. Augustine's, Canterbury, 'for the use of the neighbouring monastery of Christ Church': it is, in fact, no. 318 in Prior Eastry's catalogue of the Christ Church Library printed by Dr. M. R. James (p. 51). Moreover, the details of the rivulus and torrens point to a special knowledge of the S.E. corner of England, and I have no doubt that the fragments were written at Canterbury.

Entire pages relating to Hengist's invasion closely resemble the Historia, Brittonum, the Chartres MS. 98, and Nennius, though the narrative, instead of being continuous, is distributed under various years.

The following passages may be contrasted with Mommsen's text of the Historia Brittonum and Nennius :-

p. 179, 1. 1, 'uocatur lingua regis cantia guoralen id est cantia illius qui uocabatur guoralen.' Here, as in the Historia and Nennius, we have a Welsh corruption of Cantwaraland, but the misinterpretation is unique and 'lingua regis' (in the King's English !) is peculiar, the Historia and Nennius having 'in lingua eorum.' No such variation could have arisen at the time when the fragments were written (the King's language then being Norman-French), and the phrase suggests a region and period in which part of the population still spoke Keltic.

p. 179, 1. 2, 'in nostra autem Chent'-where 'nostra' means British-is omitted, and so is the following passage about the British king Guoyrancgon.

p. 187, 11. 15-16, ' in lingua eorum Episford': 'eorum ' is altered to 'nostra'. The following words 'in nostra autem lingua Rithergabail' are omitted. 
p. 187, 1. 18, 'Categirn'. This name (=Cat-tegirn, battle-lord, Welsh catteyrn ') must have had $t$. Our fragments babitually use $e$ and $\xi$, but rarely or never (e, except in this name, which they write Catcegirn. This $\alpha$ is almost certainly a misreading of a well-known form of te, and indicates an earlier Cattegirn.

The invasion-pages have clearly been edited by an Anglo-Saxon, and in places they are shorter than the Historia Brittonum, the Chartres MS. 98, and Nennius, as well as abundant in various readings. The only native author mentioned in the text of the MS., and the latest author mentioned, is Bede.

On the mutilated margin of $\mathrm{f}$. 30 , against the year 495 (which includes a notice of the capture of Andredes ceister), is the entry . . . 'oderici'. I conjecture this to mean that the passage referred to is an addition of Theodericus. A Theodoricus or Thodoricius appears as the donor of two books to Christ Church, Canterbury, and Dr. James dates him 'cent. xi, xii': he may have been a monk who brought them with him on his entrance.

I hope some time to ask permission of the librarians of the College libraries in Oxford to examine their Oxford bindings of the early seventeenth century for any other fragments which may still exist of this very curious chronicle.

E. W. B. Nicholson.

The Scots Magazine, January 1802, contains the following:-

'Inverness, Jan. 12.-Yesterday Major Macdonald, with the last division of Lord Macdonald's Regiment of the Isles, under the command of Lieut.-Colonel M. Macalister, arrived at Fort George after performing a march of upwards of five hundred miles from Liverpool, during which time the inclemency of the weather was such as would have impeded almost any other corps, except Highlanders. For three successive marches, from Montrose to Aberdeen, they had to cut their way through frost and snow, which they performed with the greatest alacrity, working with their spades and shovels, to the tune of their Gaelic songs, and not a single man of those that marched from Liverpool was left behind. From Aberdeen to Banff the drift and snow was often such as to prevent their seeing one another, and obliged them for security's sake to link each other by the arm from front to rear. Notwithstanding all this, the whole upon their arrival appeared neat and clean, in good health and spirits, and seemingly not in the least fatigued. Although their route from Carlisle was discretionary, yet they still continued their march (the usual halting days excepted) until their arrival at the Fort. It may not perhaps be unworthy of remark that Fort George should now be

1 'This work' [i.e. Nennius] 'introduces Arthur as the Leader of War ("dux belli ")' [Mommsen's text is bellorum] 'in accordance with the Triads and other ancient Welsh records, in which the federal sovereign is frequently termed-Catteyrn, or War-King,-and his monarchy-Catteyrnedd, or War Sovereignty' (note on page 356 o Iolo manuscripts), 